\title{
ARMY HEALTH EDUCATION OVERSEAS
}

\author{
Lieutenant- Colonel T. B. HARRISON,* \\ B.Sc., M.B., D.P.H., R.A.M.C.

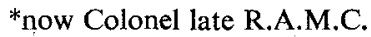

\section{Introduction}

THIS paper is based on the experience gained during an overseas tour 1961-64, the first half of the tour being spent in Cyprus and the second in Aden. W.O. II P. Grace, R.A.M.C., Army Health Inspector of Middle East Command, who was in Aden at the same time, has contributed many suggestions to this paper.

\section{Cyprus}

On arrival in Cyprus in early 1961 it was evident that the Hygiene Wing had struck a bad patch following the end of the Emergency. Although the unit had excellent basic facilities for running all the usual Army Health course, it lacked visual training aids and experienced lecturers. However, on the completion of a new lecture room in a half Twynham hut, courses were restarted in the autumn of 1961 and ended with the onset of the hot weather in June 1962. Numbers for courses were limited to not more than 12 men and no attempt was made to hold any for officers.

At first, courses were poorly subscribed, but slowly nominations increased and by the time the programme was finished in June nearly 200 men, mainly N.C.Os., had attended on one course or another. Much of the success was due to the enthusiasm of W.O. II T. Newell, B.E.M. (now W.O. I) who was with the unit for the first few months. In addition some ad hoc courses were run, for example to all N.A.A.F.I. supervisors and managers on the island.

In the autumn of 1962 another programme of courses was started with reasonable success, but, at the end of October, before the programme could be fully evaluated, the author had left for Aden.

\section{Aden}

Middle East Command, with its Headquarters in Aden is a Joint Services Command with a fully integrated medical branch. But the hospital and the bulk of general practice were run by the Royal Air Force Medical Services.

Hygienists and hygiene assistants were attached to stations and garrisons and although there was also a Pest Control Unit (P.C.U.) R.A.F., there was no hygiene wing with a training element. After obtaining approval in principle to form a small Health and Hygiene Training Unit, establishment action was taken, and in due course a unit with one $\mathrm{S} / \mathrm{Sgt}$, one Sgt. hygiene assistant and a clerk, will be formed.

While waiting for the approval of the establishment and with no resources, other than a lecture room and a great deal of unofficial help, a programme of courses was started in October, 1963, with a Sgt. P. Anderson, R.A.M.C., temporarily held surplus to strength by the unit. By co-opting medical officers, the Army Health Inspector, other hygienists and hygiene assistants, it was possible to run a full programme of courses. The success of these course was a surprise, most being over-subscribed, so that by the end of the year, seventy Army and Royal Air Force men and N.C.Os., had attended. 
From the above, it is evident that there is an excellent field overseas for health education, and it is to suggest ideas to improve health education under such receptive and favourable circumstances that this paper has been written.

\section{Discussion}

Two aspects of health education overseas are discussed, firstly, the health education of the soldier and, secondly, the trade training of the hygiene assistant.

\section{Army Health Education of the Soldier}

If facilities, good instructors, and plenty of training aids are available, the environment of an overseas station stimulates thoughts on health training. Unit commanders, once persuaded of the value of the courses, appear to be far more willing to nominate men and N.C.Os., to attend than is the case in U.K. It is also found that the students themselves take a far more personal interest in the lectures than is generally the case at home.

Practical demonstrations can in many cases be made more realistic abroad. For example in Aden-there was no difficulty in giving practical lessons in rodent control, mosquito breeding, bedbugs, fly breeding and spread of bowel diseases. However, there were serious limitations in visual aids, modern methods of teaching, latest equipment, and in particular experienced and high calibre hygiene instructors. A further lack was an adequate public health reference library, which increased the difficulty in keeping up to date. For neither in Cyprus nor in Aden were there the necessary facilities for reading and study, so that it was often most frustrating to be without the information so easily available in U.K.

This three years' experience has confirmed a previous opinion that overseas health education should be firmly linked and integrated with the teaching at the Army School of Health and its wealth of knowledge, information, materials and experience available there for continuation training.

\section{Army Health Education of the Hygiene Assistant}

The Army Health Inspector W.O. II Grace, R.A.M.C., was also of the same opinion and he was particularly concerned with the further training of hygiene assistants overseas whether or not they had qualified up to Class I tradesmen and that, once qualified, they continued their studies to keep his knowledge up to date.

\section{Improvement of Army Health Education Overseas}

Health education overseas is therefore required as results clearly demonstrate and, based on recent experience, some proposals are given below. In particular there is also a requirement to further the training and knowledge of hygiene assistants, once they have qualified as Class I tradesmen, and to keep them up to date.

1. There is a need to forge a permanent and continual liaison between the teaching at the Army School of Health and Army Health training units overseas, with an interchange of up to date information and news. The onus of maintaining this should be clearly on the Army School of Health.

2. In order to maintain an interchange of information and news, the following is necessary-- 
(a) All hygiene assistants returning from overseas should report for duty to the Army School of Health for a full week. During this time they should take part in active discussion with the staff of the school and give lectures to the staff and students relating their experiences and difficulties during the tour (a proportion of hygiene assistants from Home Commands could also be similarly asked to give their experiences).

(b) The senior army health inspectors on the strength of the Army, School of Health should, each year, tour abroad to assist with instruction at the training units, whose programme of courses for health education of the soldier would need to be geared to their visits. The latter should be for a period of not less than six weeks, during which time continuation training of hygiene assistants could also be arranged.

(c) A small library with each overseas training unit, should be maintained by the Army School of Health. It need not be large containing only a few text books some journals and in particular government publications of regulations, reports of committees etc.

(d) An exchange of training aids, lecture precis, and other visual aids would undoubtedly be a great help to all health training units.

(e) A great deal of research work and testing of new equipment is done at the Army School of Health, where discussions are held of general hygiene interest, but no information of this kind reaches hygiene assistants overseas a quarterly information bulletin issued from the Army School of Health, giving the trend of new ideas, would stimulate interest and give hygiene assistants a sense of belonging to the whole discipline of Army Health. It might also be used to publish original contributions in the field of Army Health by hygiene assistants new and bright ideas.

This may seem an ambitious scheme, but once it becomes a success it will be largely supported by the interest and help inspired by its very success. However, there will always be a need for coordination, provision of materials and publications and an initiative to maintain the liaison between all. The onus of this would rightly be on the Army School of Health, where an officer or a senior W.O. might be employed full time.

There are of course many other means of forging this link between Army Health training units and of helping one another by interchange of information etc. The ones given above are practical steps for discussion. They are not suggestions for removing responsibility and work from units overseas, but rather ones to increase their role in the general health training of the Army.

\section{Conclusion}

On the experience of a recent three years overseas, during which much time was spent in health education, advantages and drawbacks of such education overseas are briefly discussed.

1. By linking this health education with the work of the Army School of Health, by interchange of lecturers, information and experiences, it is suggested that health education throughout the Army including, continuation training of hygiene assistants, will benefit. Some means of initiating and maintaining this are given.

2. The continuation health training of the qualified hygiene assistant, while overseas, is as important as that of the soldier. The health training of both is clearly part of the same problem. 